University of Montana

ScholarWorks at University of Montana

Public and Community Health Sciences Faculty

Publications

Public and Community Health Sciences

$3-2000$

\title{
Pharmacotherapy of Smoking Cessation
}

Kolawole S. Okuyemi

Jasjit S. Ahluwalia

Kari J. Harris

University of Montana - Missoula, kari.harris@umontana.edu

Follow this and additional works at: https://scholarworks.umt.edu/pchs_pubs

Part of the Public Health Commons

Let us know how access to this document benefits you.

\section{Recommended Citation}

Okuyemi, Kolawole S.; Ahluwalia, Jasjit S.; and Harris, Kari J., "Pharmacotherapy of Smoking Cessation" (2000). Public and Community Health Sciences Faculty Publications. 29.

https://scholarworks.umt.edu/pchs_pubs/29

This Article is brought to you for free and open access by the Public and Community Health Sciences at ScholarWorks at University of Montana. It has been accepted for inclusion in Public and Community Health Sciences Faculty Publications by an authorized administrator of ScholarWorks at University of Montana. For more information, please contact scholarworks@mso.umt.edu. 


\title{
Pharmacotherapy of Smoking Cessation
}

\author{
Kolawole S. Okuyemi, MD, MPH; Jasjit S. Ahluwalia, MD, MPH, MS; Kari J. Harris, PhD, MPH
}

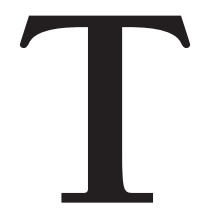

obacco use is the number one cause of preventable diseases in the United States. Smoking accounts for more than 400000 deaths yearly and 30\% of all cancer deaths. Primary care physicians have access to $70 \%$ of smokers, approximately $60 \%$ of whom are perceived to be in excellent health. Recent advances in the pharmacotherapy of nicotine addiction, including nicotine nasal spray, nicotine inhaler, bupropion hydrochloride, and overthe-counter transdermal nicotine patches, have increased the treatment options physicians can offer to smokers. Physicians, especially those in primary care specialties, should familiarize themselves with these products to improve efforts to help their patients stop smoking. This article reviews scientific data on the efficacy of approved medications, benefits, adverse effects, and appropriate use of these products. We also discuss nicotine addiction and treatment for special populations, including women, ethnic minorities, light smokers, and patients with cardiovascular and pulmonary diseases.

Arch Fam Med. 2000;9:270-281

Tobacco use is the number one cause of preventable diseases in the United States. Smoking accounts for about 435000 deaths yearly and $30 \%$ of all cancer deaths. ${ }^{1}$ Cigarette smoking is responsible for $\$ 50$ billion annually in direct medical costs, and $\$ 47$ billion in indirect, nonmedical costs. ${ }^{2}$ Despite widespread efforts to educate the public on the risks of smoking, the prevalence of smoking in the United States remains high. Approximately 46 million American adults are still current smokers. ${ }^{3}$ Although smoking prevalence for US adults has fallen from $42 \%$ in 1965 to $25.5 \%$ in $1997,{ }^{4}$ the proportion of heavy smokers is higher today than 20 years ago. ${ }^{5}$ One of the goals of Healthy People 2000 is to increase by $75 \%$ the proportion of primary care providers who routinely provide smoking cessation counseling for their patients who smoke. ${ }^{1}$ Primary care clinicians have access to approximately 36 million (70\%) of the 50 million people who smoke, including $61 \%$

From the Departments of Family Medicine (Dr Okuyemi), Preventive Medicine (Drs Okuyemi, Ahluwalia, and Harris), and Internal Medicine (Dr Ahluwalia), School of Medicine, University of Kansas, Kansas City. Dr Ahluwalia has received honoraria and grant support from Glaxo Wellcome Inc, Research Triangle Park, NC; SmithKline Beecham Consumer Healthcare, Pittsburgh, Pa; and McNeil Consumer Products Co, Fort Washington, $\mathrm{Pa}$. of smokers who considered themselves to be in "excellent health." 6,7

\section{HEALTH CONSEQUENCES OF CIGARETTE SMOKING}

Cigarette smoking is associated with significant morbidity and mortality, and remains a continued significant threat to public health. For years, studies have documented that smokers are at increased risk of developing numerous diseases including cardiovascular disease (eg, coronary artery disease, stroke, hypertension, and peripheral vascular disease), cancer (eg, of the lung, stomach, and bladder), respiratory disease (eg, chronic bronchitis and chronic obstructive pulmonary disease), and gastric ulcers. ${ }^{8}$ In addition, cigarette smoking may create an antiestrogen effect, accelerating early menopause (and consequently osteoporosis and other conditions related to estrogen deprivation), cataracts, and wrinkling. ${ }^{9}$ While mortality among nonsmokers has remained stable, death rates among smokers from lung cancer, coronary heart disease, and other smoking-related diseases has increased from 26 per 100000 to 155 per 100000 population in women and from 187 per 100000 to 341 per 100000 among 
men, from 1959 to 1986 , respectively. ${ }^{10}$ Some minority groups, such as African Americans, bear a disproportionate share of health consequences of smoking, having the highest overall cancer mortality rates compared with other racial and ethnic groups. ${ }^{11}$

\section{IMPACT OF SMOKING CESSATION}

Smoking cessation significantly reduces most of the increased health risks that smokers have incurred. The degree of improvement, however, depends on the disease process involved, the amount of damage produced, and the reversibility of this damage at the time of cessation. According to the 1990 US Surgeon General's report, the higher allcause mortality risk in smokers returns to that of never-smokers within 10 to 15 years of quitting. ${ }^{12}$

Former smokers reduce their risk of developing coronary heart disease $50 \%$ within 1 year of quitting, and after 2 years of quitting smoking, former smokers have only twice the risk of having a first myocardial infarction as never-smokers. ${ }^{12}$ After 4 years, this risk becomes equal to that of never-smokers. Cancer risk varies with the type of cancer involved. The risk of lung cancer in former smokers, for example, always remains higher than that for never-smokers; however, this risk decreases progressively and considerably with the number of years of abstinence. ${ }^{8}$

\section{NICOTINE DEPENDENCE}

Cigarette smoking is an addiction, as powerful in many respects, as cocaine or opiate dependence. ${ }^{13}$ Evidence that tobacco use is more likely to lead to dependence than any other drug use is supported by the fact that among those who have ever tried even a single cigarette, almost one third develop nicotine dependence. ${ }^{14}$ Although most smokers want to quit, they experience wellcharacterized barriers and withdrawal symptoms during their attempts to quit, and they are largely unsuccessful in quitting. In fact, spontaneous quit rates without any cessation intervention range from $2 \%$ to $5 \%$ in the United States. ${ }^{15}$
Nicotine acts on nicotinic acetylcholine receptors in both the central nervous system and the peripheral nervous system. Its psychoactive effects are facilitated when nicotine binds to these acetylcholine receptors, producing an enhanced alertness and a mild euphoria. ${ }^{16}$ However, exogenous nicotine binds to the acetylcholine receptors for longer than endogenous neurotransmitter, thereby producing a secondary blockade of these receptors. Over time, the body adapts to this chronic secondary antagonism and upregulates its central nervous system acetylcholine receptors. This is the physical basis for nicotine tolerance. The increased number of nicotine receptors makes the normal amount of acetylcholine released into the synapse insufficient to maintain the previous mood, and the biological basis for the physical dependence is established.

\section{TRENDS IN SMOKING CESSATION}

Quitting smoking is exceedingly difficult. Surveys show 74\% of smokers report a desire to quit smoking and $70 \%$ of smokers have made previous attempts to quit smoking, yet success in quitting remains low. ${ }^{5}$ The difficulty in quitting that most smokers encounter reflects both a habit and a physiological addiction. In addition, cessation involves discontinuing a dependency that smokers acquired at a vulnerable period in their lives. Cessation prevalence, or the quit ratio, defined as the proportion of ever-smokers who are former smokers (former/ever), has increased since 1965 from 24\% to $50 \%$ in $1993 .{ }^{3}$ Although a sex difference in smoking cessation exists, with a quit ratio of $52 \%$ for men and $47 \%$ for women, the greater tendency of men to switch from cigarettes to other tobacco products may account for this difference. ${ }^{3}$

\section{GUIDELINES FOR SMOKING CESSATION}

In 1996, the Agency for Health Care Policy and Research (AHCPR) published its Smoking Cessation Clinical Practice Guideline. ${ }^{17}$ The Agency recommended a 5-step approach, also known as the 5A's, to be used by primary care physicians: Asksystematically identify all tobacco users at every visit, incorporate smoking status as fifth vital sign; Advisestrongly urge all smokers to quit; Assess - determine patient's willingness to make a quit attempt; Assist-if patient is willing to make a quit attempt, help set a quit date, and encourage nicotine replacement therapy (NRT) except in special circumstances; and Arrange-schedule follow-up contact. The recommendation by the AHCPR that NRT (specifically nicotine gum and transdermal patches) be offered to all smokers wishing to quit was made since these were the only drugs approved for smoking cessation when the guidelines were developed. However, a number of other treatment options, including other NRT and nonnicotine products, have become available since the release of the guidelines. The AHCPR guidelines are currently being updated and will be released in mid- 2000 .

\section{NONPHARMACOLOGICAL TREATMENT}

Although the focus of this article is pharmacotherapy, a brief review of other available interventions is provided to put pharmacotherapy in perspective. Behavioral interventions are beneficial to the longterm success of smoking cessation. Studies have shown that brief ( 5 minutes or less) advice on quitting given by physicians to smokers during an office visit have resulted in higher quit rates compared with no advice. ${ }^{18}$ In a review of 20 studies conducted in primary care settings, Law and Tang ${ }^{19}$ reported that $2 \%$ of all smokers who received brief physician advice quit smoking as a direct consequence of it, compared with $0.1 \%$ in smokers who received no advice. With additional encouragement and support (follow-up letters, telephone calls, demonstration of spirometry, and additional visits), quit rates increased to $5 \%$. In that same review, supportive group sessions for smokers produced similar quit rates as no advice. While these results suggest that more intensive interventions achieve higher quit rates, time con-

$\overline{\text { ARCH FAM MED/VOL 9, MAR } 2000 \text { WWW.ARCHFAMMED.COM }}$ 
straints experienced by primary care physicians during office visits ${ }^{20}$ and reluctance of many patients to enter intensive programs ${ }^{21}$ make brief interventions the more feasible approach. Readers interested in other nonpharmacological treatments should consult other sources for more detailed reviews. ${ }^{22-24}$ The low quit rates associated with unaided and nonpharmacological quit attempts demands that pharmacological treatment be offered to all smokers planning to quit unless there is a medical contraindication.

\section{PHARMACOLOGICAL TREATMENT}

In 1984, the Food and Drug Administration (FDA) approved the first pharmacological agent, nicotine polacrilex gum, for smoking cessation. It was the only NRT product available until the introduction in 1992 of transdermal nicotine patch, the nicotine nasal spray in 1996, bupropion hydrochloride in 1997, and the nicotine inhaler in 1998 (Table 1).

\section{Nicotine Replacement Therapy}

Since nicotine dependence is a significant element of most patients' smoking behavior, one strategy for aiding cessation is to pharmacologically replace nicotine. Smokers can then engage in behavioral therapy to decondition their conditioned triggers without experiencing withdrawal symptoms during abstinence. In general, indications and contraindications for use of all NRT products are similar. Although the product insert labels for all NRT products advise caution in their use for patients with cardiovascular diseases, studies have shown that these products cause fewer cardiovascular effects than nicotine delivered by tobacco smoke, and are generally safe for the vast majority of smokers. ${ }^{26}$ Nicotine replacement products that are FDA approved include nicotine polacrilex gum, transdermal nicotine patches, nicotine nasal spray, and nicotine inhaler. Only the first 2 products are available without prescription.

Nicotine Polacrilex Gum. In 1984, nicotine polacrilex gum (Nicorette, SmithKline Beecham Consumer Healthcare, Pittsburgh, $\mathrm{Pa}$ ) became available in the United States as a prescription-only medication. Approval for nonprescription sale was given in 1995 for 2-mg and 4-mg doses. A box of 48 pieces costs approximately $\$ 30$ (Table 2). The nicotine is buffered in sodium bicarbonate, which facilitates absorption through the buccal mucosa. Patients generally absorb 50\% of the nicotine in each piece of gum, providing a bolus of nicotine that reaches peak venous plasma concentrations within 30 minutes. The venous level of nicotine then slowly tapers in a pattern resembling, but significantly slower and less potent than, that from cigarette smoke. To benefit from the gum, patients must

Table 1. Drugs Approved for Smoking Cessation*

\begin{tabular}{|c|c|c|c|c|}
\hline Drug & Usual Dosage & Advantages & Disadvantages & Contraindications \\
\hline $\begin{array}{l}\text { Nicotine polacrilex } \\
\text { (nicotine gum) }\end{array}$ & $\begin{array}{l}\text { Start with } 2 \mathrm{mg} \text {, use } 4 \mathrm{mg} \text { if } \\
\text { not successful with } 2 \mathrm{mg} \text {; } \\
\text { chew } 1 \text { gum every } 1-2 \mathrm{~h} \\
\text { (maximum } 30 \text { pieces/d of } \\
2-\mathrm{mg} \text { gum or } 15 \text { pieces/d } \\
\text { of } 40 \text {-mg gum); usual length } \\
\text { of treatment is } 1-3 \text { mo }\end{array}$ & $\begin{array}{l}\text { Convenient, flexible dosing; } \\
\text { faster delivery of nicotine } \\
\text { than the patch }\end{array}$ & $\begin{array}{l}\text { No food or drink } 15 \text { min } \\
\text { before use; frequent } \\
\text { dosing; jaw pain, mouth } \\
\text { soreness, dyspepsia, } \\
\text { hiccups }\end{array}$ & $\begin{array}{l}\text { Dental problems; TMJ syndrome; } \\
\text { use in pregnancy† (category C) } \\
\text { if nonpharmacological } \\
\text { measures fail and if benefits } \\
\text { outweigh risks; avoid use } \\
1 \text { mo post-MI, serious } \\
\text { arrhythmias, or unstable } \\
\text { angina, unless benefits } \\
\text { outweigh risks }\end{array}$ \\
\hline $\begin{array}{l}\text { Transdermal } \\
\text { nicotine patch } \\
\text { (Nicoderm, } \\
\text { Habitrol, } \\
\text { Nicotrol) }\end{array}$ & $\begin{array}{l}\text { Nicoderm, Habitrol: } 21 \mathrm{mg} / 24 \mathrm{~h} \\
\text { for } 6-8 \mathrm{wk} \text {, then } 14 \mathrm{mg} / 24 \mathrm{~h} \\
\text { for } 2-4 \mathrm{wk} \text {, then } 7 \mathrm{mg} / 24 \mathrm{~h} \\
\text { for } 2-4 \mathrm{wk} \text {; Nicotrol: } 15 \\
\mathrm{mg} / 16 \mathrm{~h} \text { for } 6 \text { wk }\end{array}$ & $\begin{array}{l}\text { Easy to use; daily application; } \\
\text { OTC availability; overnight } \\
\text { use may reduce early } \\
\text { morning cravings; few side } \\
\text { effects }\end{array}$ & $\begin{array}{l}\text { Skin irritation; less flexible } \\
\text { dosing; slow delivery of } \\
\text { nicotine; wearing at } \\
\text { night may cause sleep } \\
\text { problems }\end{array}$ & $\begin{array}{l}\text { Pregnancy (category D) and } \\
\text { cardiovascular warnings } \\
\text { same as for gum }\end{array}$ \\
\hline $\begin{array}{l}\text { Nicotine nasal spray } \\
\text { Nicotrol NS } \\
\text { (nasal spray) }\end{array}$ & $\begin{array}{l}\text { Use 1-2 doses/h (minimum, } \\
8 \text { doses/d; maximum, } \\
40 \text { doses/d); usual length } \\
\text { of treatment is } 3 \text { mo; taper } \\
\text { over } 4-6 \text { wk }\end{array}$ & $\begin{array}{l}\text { Flexible dosing; fastest delivery } \\
\text { of nicotine among all } \\
\text { products; reduces cravings } \\
\text { within a few minutes }\end{array}$ & $\begin{array}{l}\text { Frequent dosing; nose and } \\
\text { eye irritation; cough }\end{array}$ & $\begin{array}{l}\text { Pregnancy (category D) and } \\
\text { cardiovascular warnings } \\
\text { same as for gum }\end{array}$ \\
\hline $\begin{array}{l}\text { Nicotine inhaler } \\
\text { (Nicotrol Inhaler) }\end{array}$ & $\begin{array}{l}\text { 10-mg cartridge, but only } 4 \text { mg } \\
\text { absorbed; } 6-16 \text { cartridges/d; } \\
\text { treat for } 3 \text { mo, taper over } \\
\text { 6-12 wk }\end{array}$ & $\begin{array}{l}\text { Flexible dosing mimics } \\
\text { hand-to-mouth behavior; } \\
\text { few side effects }\end{array}$ & $\begin{array}{l}\text { Mouth and throat irritation; } \\
\text { frequent dosing } \\
\text { necessary }\end{array}$ & $\begin{array}{l}\text { Pregnancy (category D) and } \\
\text { cardiovascular warnings } \\
\text { same as for gum }\end{array}$ \\
\hline $\begin{array}{l}\text { Bupropion } \\
\text { (hydrochloride) } \\
\text { SR (Zyban) }\end{array}$ & $\begin{array}{c}150 \mathrm{mg} \text { orally once daily for } 3 \mathrm{~d} \text {, } \\
\text { then twice daily for } 7-12 \text { wk }\end{array}$ & $\begin{array}{l}\text { Nonnicotine; tablet form; easy } \\
\text { to use; may be used with NRT }\end{array}$ & $\begin{array}{l}\text { Insomnia, dry mouth, } \\
\text { headache, tremors }\end{array}$ & $\begin{array}{l}\text { Pregnancy (category B); seizure } \\
\text { disorder; concurrent use of } \\
\text { Wellbutrin (former trade name) } \\
\text { or an MAO inhibitor; bulimia or } \\
\text { anorexia nervosa }\end{array}$ \\
\hline
\end{tabular}

* OTC indicates over the counter; NRT, nicotine replacement therapy; TMJ, temporomandibular joint; MI, myocardial infarction; SR, sustained release; and MAO, monoamine oxidase.

$\dagger$ Pregnancy risk definitions ${ }^{25}$ are as follows: $A$, controlled studies in women fail to demonstrate a risk to the fetus; $B$, animal studies have either not demonstrated a fetal risk or have shown an adverse effect not confirmed in controlled studies in women; $C$, studies in women and animals not available or animal studies have revealed adverse effects on the fetus but there are no controlled studies in women; and D, there is no positive evidence of human fetal risk, but benefits from use may be acceptable for a serious disease if safer drugs are unavailable or ineffective. 
chew at least 10 pieces of the gum per day to absorb about half of the daily dose of nicotine that they would otherwise receive from cigarettes. Patients who smoke fewer than 15 cigarettes per day should use the 2-mg dose while the 4-mg dose should be reserved for those who smoke more. The gum should be chewed slowly until a "peppery" taste appears in the mouth, and then "parked" between the gum and the cheek until the taste fades. Intermittent chewing and "parking" should continue for 30 minutes.

The gum may be difficult to use correctly since it requires special chewing techniques, and a high frequency of use. Adverse effects from the gum include jaw fatigue and soreness and gastrointestinal upset, such as gaseous distention, hiccups, and nausea. ${ }^{27}$ The gum is contraindicated in patients with gastric ulcers, and is difficult to use for patients with dentures. ${ }^{28}$ Abruptly stopping polacrilex gum use may precipitate nicotine withdrawal symptoms, especially when used beyond the recommended 3 months. ${ }^{29}$ Up to $20 \%$ of smokers who successfully quit taking the gum use it for more than 1 year. ${ }^{30}$ Perhaps secondary to its demanding use requirements, nicotine gum has been shown to be more efficacious when used in specialized clinics than when used in general medicine practices. In a meta-analysis of randomized controlled trials, the success rates in specialized cessation clinics were significantly higher with nicotine gum than with placebo gum at 6 months (27\% vs $18 \%$ ) and 12 months (23\% vs $13 \%) .{ }^{31}$ In contrast, success rates in general medical practices were no different with the gum and placebo (11.7\%) at 6 months. ${ }^{32}$ Higher quit rates in specialized smoking cessation clinics may be a result of more in-depth counseling, better trained counselors, and possibly smokers with higher motivation to quit.

Transdermal Nicotine Patches. Three major brands of transdermal nicotine patches are currently available in the United States: Habitrol (Novartis Consumer Health, Summit, NJ), Nicoderm CQ (SmithKline Beecham Consumer Healthcare), and Nicotrol (McNeil Consumer Prod- ucts Co, Fort Washington, Pa). Only the first product requires a prescription (Table 1). Patch brands differ in the rate control mechanisms, starting dose, and weaning regimen. Patches are sold in 1- to 2-week boxes at a cost of approximately $\$ 30$ per week (Table 2) and initial therapy of some of the products includes a cassette tape and a self-help booklet. The Habitrol and Nicoderm CQ patches are available as 21-mg (6-8 weeks), 14-mg (2-4 weeks), and 7-mg (2-4 weeks) regimens. The overall regimen for using these 2 patch brands is consistent: after approximately 1 to 2 months, patients switch to progressively lower-dose patches until they are effectively weaned off of the patch. Patients who smoke at least 10 cigarettes per day can begin with the highest dose patch. The Nicotrol patch is a single-dose patch of $15 \mathrm{mg}$, and is intended for daytime use only as a 16hour patch (ie, removal before going to sleep). Treatment is recommended for 6 weeks. The transdermal nicotine patch is applied to the skin daily and nicotine is gradually absorbed throughout the day. Each patch delivers $0.9 \mathrm{mg} / \mathrm{h}$ of nicotine, and delivery reaches its daily peak after approximately 6 hours. ${ }^{16} \mathrm{Cumu}-$ latively, the nicotine reaches therapeutic peak levels (about 13-17 ng/ $\mathrm{mL}$ ) after 2 to 3 days, when the risk for smoking relapse is greatest. Serum levels decline 1 to 2 hours after removing the patch.

Continuous controlled release of nicotine through a transdermal nicotine patch resolves some of the problems associated with nicotine gum, such as difficulty with use and side effects. Also, the potential for addiction to the medication is much lower by daily self-administration of nicotine replacement with the patch than hourly replacement with the gum. ${ }^{30,33}$ The most common side effects of the transdermal nicotine patches include a mild skin reaction with pruritis and edema. Less commonly, sleep disturbance has been reported with the 24-hour patches. The transdermal patches are contraindicated for patients with systemic eczema, unstable angina, pregnancy, and within 1 month of a myocardial infarction. A number of studies have shown the success of the patch under controlled and realworld settings, ${ }^{34,35}$ including innercity minority populations. ${ }^{36}$ Efficacy of the nicotine patch is reported to be about $20 \%$ to $30 \%$ at 6 months, which is approximately double the cessation rate for placebo. ${ }^{37}$ One important question that remains unanswered is how much behavioral therapy is needed to maximize the therapeutic effect of the transder-

\begin{tabular}{|c|c|c|c|}
\hline Drug (Manufacturer) & Dosage & Quantity* & Cost, \$† \\
\hline \multirow{4}{*}{$\begin{array}{l}\text { Nicorette (SmithKline Beecham } \\
\text { Consumer Healthcare) }\end{array}$} & $2 \mathrm{mg}$ & $48 \mathrm{~s}$ & 28.50 \\
\hline & & $108 \mathrm{~s}$ & 49.11 \\
\hline & $4 \mathrm{mg}$ & $48 \mathrm{~s}$ & 32.08 \\
\hline & & $108 \mathrm{~s}$ & 55.26 \\
\hline \multirow{2}{*}{$\begin{array}{l}\text { Nicoderm CQ (SmithKline Beecham } \\
\text { Consumer Healthcare) }\end{array}$} & $7 \mathrm{mg} / 24 \mathrm{~h}$ & $7 \mathrm{~s}$ & 28.50 \\
\hline & $\begin{array}{l}14 \mathrm{mg} / 24 \mathrm{~h} \\
21 \mathrm{mg} / 24 \mathrm{~h}\end{array}$ & $14 \mathrm{~s}$ & 49.11 \\
\hline \multirow[t]{3}{*}{ Habitrol (Novartis Consumer Health) } & $7 \mathrm{mg} / 24 \mathrm{~h}$ & $30 \mathrm{~s}$ & 120.52 \\
\hline & $14 \mathrm{mg} / 24 \mathrm{~h}$ & $30 \mathrm{~s}$ & 127.22 \\
\hline & $21 \mathrm{mg} / 24 \mathrm{~h}$ & $30 \mathrm{~s}$ & 138.87 \\
\hline \multirow[t]{3}{*}{ Nicotrol (McNeil Consumer Products Co) } & $15 \mathrm{mg} / 16 \mathrm{~h}$ & 14s starter plus 2 refills & 43.06 \\
\hline & $15 \mathrm{mg} / 16 \mathrm{~h}$ & 7s refill & 24.71 \\
\hline & & $14 \mathrm{~s}$ refill & 43.06 \\
\hline $\begin{array}{l}\text { Nicotrol NS (nasal spray) } \\
\text { (McNeil Consumer Products Co) }\end{array}$ & $0.5 \mathrm{mg} /$ inhalation & $10 \mathrm{~mL}$ & 40.80 \\
\hline $\begin{array}{l}\text { Nicotrol Inhaler } \\
\quad \text { (McNeil Consumer Products Co) }\end{array}$ & $10 \mathrm{mg}$ & $42 s$ & 40.80 \\
\hline \multirow[t]{2}{*}{ Zyban (Glaxo Wellcome Inc) } & $150 \mathrm{mg}$ & $60 \mathrm{~s}$ & 83.74 \\
\hline & & $30 \mathrm{~s}$ & 49.47 \\
\hline
\end{tabular}

* Given as number of pieces of gum, patches, or cartridges.

$\dagger$ Average wholesale prices from the 1999 Drug Topics Red Book (Medical Economics Co, Montvale, NJ). 
mal nicotine patch. Two metaanalyses published in 1994 have attempted to address this issue. ${ }^{35,37}$ The analyses concluded that intensive follow-up was more efficacious but the results were not statistically significant.

Availability of the transdermal patches as nonprescription products improves access to their use, which theoretically would increase their public health effectiveness. Some studies have reported similar quit rates in double-blind, placebocontrolled trials in nonprescription setting when compared with the prescription setting. ${ }^{38,39}$ However, patients enrolled in the nonprescription arm of these studies were already motivated to quit smoking, and may not be representative of most smokers.

Nicotine Nasal Spray. Nicotine nasal spray (Nicotrol NS, McNeil Consumer Products Co) is a relatively new (FDA approved in 1996) form of nicotine replacement delivery system, available only by prescription. It is designed to deliver nicotine more rapidly than the gum or patch, but less rapidly than smoking cigarettes. ${ }^{40}$ Users tend to selfadminister to plasma nicotine concentrations that are approximately $50 \%$ of those achieved by smoking. ${ }^{41}$ The rapid delivery and relatively high plasma concentrations make the nasal spray more suitable for treating withdrawal symptoms, and especially beneficial to highly dependent smokers. When nicotine is administered by nasal spray, peak plasma concentrations are reached at a rate comparable to that from cigarette smoking, and thus can be used for treating acute nicotine withdrawal symptoms. The nozzle is inserted into the nostrils similar to the technique for antihistamine or steroid nasal sprays. Each spray (.05 mL) delivers $0.5 \mathrm{mg}$ of nicotine, and a dose is a spray in each nostril. Patients should be started with 1 to 2 doses per hour, which may be titrated up to the maximum dose of $5 \mathrm{mg} / \mathrm{h}$ or $40 \mathrm{mg} / \mathrm{d}$ for 3 months. Recommended dosing is 1 to 2 doses every hour for 6 to 8 weeks, followed by 4 to 6 weeks of gradual reduction by halving the dose, and decreasing the daily fre- quency. Although use of the spray may be stopped abruptly by many patients without withdrawal effects, some patients may need tapering. Although no tapering strategy has been shown to be optimal, a number of tapering strategies can be used. Such strategies include having patients use half a dose ( 1 spray) at a time, use spray less frequently, skip a dose, try to meet a steadily reducing usage target, and setting a date to stop use of the spray. ${ }^{42}$

In a randomized, doubleblind, placebo-controlled study, ${ }^{40}$ $32 \%$ of patients using active spray were abstinent at 6 months compared with $12 \%$ taking the placebo. The rates at 1 year after quit dates were $26 \%$ and $10 \%$ for active and placebo sprays, respectively. These findings suggest that the nicotine nasal spray is helpful in aiding smoking cessation. The most commonly reported side effects of the nicotine nasal spray include nasal irritation, runny nose, sneezing, throat irritation, coughing, and watery eyes. Patients develop tolerance to these effects within the first week. Less frequently, heart pounding, nausea, headache, dizziness, and sweating have been reported.

Nicotine Inhaler. In 1998, the nicotine inhaler (Nicotrol Inhaler, McNeil Consumer Products Co) became available as a prescription drug for smoking cessation. It consists of a mouthpiece and a plastic cartridge designed to deliver $4 \mathrm{mg}$ of nicotine from a porous plug containing $10 \mathrm{mg}$ of nicotine. The cartridge also contains $1 \mathrm{mg}$ of menthol as an inactive ingredient to reduce irritation by nicotine. The cartridge is inserted into the mouthpiece prior to use. Nicotine inhaler is different from other inhalers in that most of the nicotine released from the inhaler is absorbed in the mouth, with less than 5\% reaching the lower respiratory tract. ${ }^{43} \mathrm{~A}$ major difference between the nicotine inhaler and other NRT products is that it mimics the hand-to-mouth routine similar to cigarette smoking. It may therefore reduce fears associated with abrupt cessation of the hand-to-mouth ritual.

In a double-blind, placebocontrolled trial, individuals using ac- tive inhalers had continuous abstinence rates of $29 \%$ and $24 \%$ compared with $14 \%$ and $10 \%$ with placebo at 6 weeks and 3 months postquit date, respectively. ${ }^{44}$ Other studies have reported similar findings. ${ }^{45}$ The average daily dose in clinical trials was more than 6 cartridges for patients who were able to quit smoking successfully. Patients should therefore be encouraged to use at least 6 cartridges per day for the first 3 to 6 weeks of treatment. Patients should be allowed to selftitrate dosage based on severity of withdrawal signs and symptoms. Treatment should be continued at the selected dose for 6 to 12 weeks in patients who have successfully quit smoking, followed by tapering over 3 months. A common tapering strategy used in some trials ${ }^{45}$ was to reduce usage by $25 \%$ monthly for 3 months. Each puff releases approximately $16 \mu \mathrm{g}$ at room temperature, and each inhaler is designed to produce approximately 300 puffs. ${ }^{46}$ An intensive inhalation regimen (about 80 deep inhalations over 20 minutes) is required to approximate the amount of nicotine delivered by smoking 1 cigarette. The same cartridge can be used up to 5 times before replacing with a new one. The device should be stored at room temperature as it may lose significant bioavailability at temperatures below $10^{\circ} \mathrm{C}$. The mouthpiece is reusable and should be cleaned regularly. Adverse effects are generally mild consisting of throat irritation and cough.

\section{Nonnicotine Drugs}

Several nonnicotine products have been tested for smoking cessation, but only one has been approved by the FDA. Initially developed and marketed as an antidepressant under the trade name Wellbutrin, the sustainedrelease form was approved in 1997 as an aid for smoking cessation under a new the trade name, Zyban (Glaxo Wellcome Inc, Research Triangle Park, NC). Bupropion is an aminoketone, chemically unrelated to other known antidepressants. It has both doperminergic and adrenergic actions. ${ }^{47}$ Although the mechanism by which bupropion enhances ability of smokers to quit smoking is

$\overline{\text { ARCH FAM MED/VOL 9, MAR } 2000 \text { WWW.ARCHFAMMED.COM }}$ 
not known, it is presumed to involve both doperminergic and adrenergic mechanisms. ${ }^{48}$ Bupropion is an alternative for smokers who either cannot tolerate NRT or prefer nonnicotine treatment. In a randomized, double-blind, placebocontrolled trial, ${ }^{49} 27 \%$ of patients who received the active drug were abstinent at 6 months, compared with $16 \%$ of patients taking placebo. An earlier study ${ }^{50}$ also reported similar results. The recommended dose is $150 \mathrm{mg}$ orally once daily for 3 days, then $150 \mathrm{mg}$ twice daily (at least 8 hours apart) for 7 to 12 weeks. Although 2 brand products are available for bupropion, Zyban and Wellbutrin, we recommend that Zyban be prescribed as "do not substitute" because its package comes with the Zyban Advantage Plan, which includes self-help brochures and a workbook and access to a personalized support program for smoking cessation. Unlike NRT, patients should set their quit date 1 to 2 weeks after initiating therapy with bupropion to allow steady state serum levels to be achieved. Cigarette smoking does not significantly affect the pharmacokinetics of buproprion. ${ }^{47}$ Adverse effects are generally mild, consisting of insomnia and dry mouth. The latter effect may be minimized by encouraging patients to drink small amounts of water at frequent intervals, and insomnia can be reduced by avoiding bedtime doses. Initial concerns about increased risk of seizures have not been confirmed. ${ }^{47}$ Recent studies ${ }^{49}$ with $300 \mathrm{mg} / \mathrm{d}$ or less of sustainedrelease bupropion hydrochloride for smoking cessation have found the risk of seizures to be similar to that of other antidepressants. The drug is pregnancy category B, and contraindicated in patients with a history of seizures, anorexia or bulimia, head trauma, or heavy alcohol use.

\section{Combination Drug Therapy}

Although all the drugs discussed above have only been approved as single pharmacological agents, combination treatments may be appropriate for smokers who are unable to quit with monotherapy.

Combined Use of NRT Products. Given its acute delivery and, therefore, usefulness for acute cravings, some physicians began using polacrilex gum in conjunction with the transdermal nicotine patches. In a double-blind, placebo-controlled trial published in 1995, Kornitzer et $\mathrm{al}^{51}$ randomly assigned 374 smokers (who smoked at least 10 cigarettes a day) to 3 groups: placebo gum plus placebo patch, active patch plus placebo gum, and active patch plus active gum. They reported that the addition of nicotine gum to the patch significantly increased quit rates from $23 \%$ to $34 \%$ at 12 weeks and from $15 \%$ to $28 \%$ at 24 weeks. Also, a review of 4 studies that documented statistical significance ${ }^{52}$ concluded that for heavy smokers, combined use of 5 to 7 pieces per day of polacrilex gum with the 16- or 24hour transdermal patch significantly reduces withdrawal symptoms and increases initial cessation rates more than use of either product alone. Side effects were not significantly increased by combined use of nicotine patch and gum. A recent study ${ }^{53}$ also reported higher quit rates when the patch is combined with the nasal spray than with the patch alone $(51 \%$ vs $35 \%$ at 6 weeks and $37 \%$ vs $25 \%$ at 3 months for the combination and patch only, respectively). Combination treatments should be considered for smokers with significant craving or withdrawal despite adequate doses of single agents and should be continued for 3 to 6 months.

Combined Use of Transdermal Nicotine Patch and Bupropion. In a recent double-blind, placebocontrolled study ${ }^{54}$ comparing sustained-release bupropion, a nicotine patch, and both for smoking cessation in 732 smokers, abstinence rates at 12 months were $35.5 \%$ in the combination (bupropion plus nicotine patch) group compared with $30.3 \%$ for bupropion alone, $16.4 \%$ for nicotine patch alone, and $15.6 \%$ for the placebo patch and pill group. They concluded that abstinence rates were significantly higher with bupropion in combination with nicotine patch than with the patch alone. However, the difference in abstinence rates between the combination treatment and bupropion alone was not statistically significant. These findings suggest that bu- propion may be used in combination with the nicotine patch in patients without contraindications to either drugs when deemed necessary. Patients should be started on bupropion hydrochloride at 150 $\mathrm{mg} / \mathrm{d}$ for 3 days, then $150 \mathrm{mg}$ twice daily for 1 to 2 weeks prior to quit date. Transdermal nicotine patch therapy should then be added starting on the quit date. We recommend that treatment be continued for 3 to 6 months.

\section{SPECIAL POPULATIONS}

\section{Minorities}

Tobacco use varies within and among racial and ethnic minority groups in the United States. ${ }^{55}$ Members of racial and ethnic minorities populations bear a disproportionate share of adverse health consequences of tobacco use, such as cancer, cardiovascular diseases, and preterm births. ${ }^{11,56}$ Paradoxically, the 1998 Surgeon General's report noted that ethnic and racial minorities are less likely than the general population to participate in smoking cessation groups and to receive cessation advice from health care providers. ${ }^{55}$ Compared with whites, African Americans smoke fewer cigarettes, but are more likely to smoke mentholated brands and brands with higher tar and nicotine content. ${ }^{57}$ Although African American adults are more likely to have a greater number of quit attempts than white Americans in any given year, these attempts are 34\% less successful than they are for whites. ${ }^{3,58} \mathrm{Re}$ search in pharmacological intervention for smoking cessation has been conducted almost exclusively in white, middle-class populations. A double-blind, randomized, placebocontrolled trial of the transdermal nicotine patch among inner-city African Americans ${ }^{36}$ found that the patch significantly improves quit rates in this population. The results from a National Cancer Institute-funded clinical trial on the efficacy of bupropion among African Americans will not be available for another year. Another study ${ }^{59}$ in Hispanic smokers found that the transdermal nicotine patch resulted in nearly doubling of quit rates com-

$\overline{\text { ARCH FAM MED/VOL 9, MAR } 2000 \text { WWW.ARCHFAMMED.COM }}$ 
pared with placebo. Due to paucity of data on pharmacological interventions among minority populations, the AHCPR recommended that clinicians who see minority patients should offer treatments proven to be effective for the general population. Until more conclusive data become available, physicians should follow the AHCPR recommendations that "whenever possible, smoking cessation treatment should be modified or tailored to be appropriate for ethnic or racial populations with whom they are used." ${ }^{17} \mathrm{Nev}-$ ertheless, clinicians should be aware of the limitations of such generalization.

\section{Women and Pregnancy}

Although the number of male smokers continues to outnumber female smokers (26\% for men vs $21 \%$ for women in 1997), mortality from lung cancer in women continues to rise. ${ }^{60}$ In fact, lung cancer, mostly due to smoking, is the leading cause of cancer deaths in women. ${ }^{60}$ Current data suggest that women are quitting at same rate as men. ${ }^{61} \mathrm{Fac}-$ tors that undermine cessation in women include depression, social support, and weight gain. ${ }^{62}$ It is not clear whether women experience more withdrawal symptoms than men during abstinence. ${ }^{61}$ Some data have suggested that men do better with NRT, but these results have not been replicated..$^{63}$ Smoking during pregnancy has well-documented consequences on maternal and fetal health, including low birth weight, spontaneous abortion, and preterm births.$^{64}$ Many pregnant women find it difficult to quit on their own. ${ }^{65}$ Quitting cigarette smoking during early pregnancy reduces the risk of low birth weight. ${ }^{12}$ Even women who quit smoking as late as the 30th week of gestation have infants with higher birth weights than those who continue to smoke. ${ }^{41}$ Current evidence suggests that behavioral therapy for pregnant smokers is effective $e^{66}$ and should be encouraged before pharmacological approaches are used. All the NRT products are pregnancy category $\mathrm{D}$ except the gum, which is category $\mathrm{C}$. The level of nicotine to which the fetus is exposed with the patch or gum is lower than that from cigarettes. Reviews on use of the gum and patch during pregnancy suggest that their use should still be considered. The risk-benefit ratio appears favorable if efforts to quit without medication has failed ${ }^{67}$ Use of nicotine inhaler or nicotine nasal spray during pregnancy has not been examined. Bupropion carries pregnancy category B label, and could be used if nonpharmacological efforts have failed. The risks and benefits of any medication used for smoking cessation during pregnancy should be explained to mother.

\section{Smokers With Cardiovascular Diseases}

Smokers are clearly at higher risk of dying from smoking-related cardiovascular diseases such as coronary artery disease, stroke, congestive heart failure, and other heart diseases ${ }^{68}$ Also important is the fact that the risk of cardiovascular disease decreases markedly within 1 year of stopping smoking and approximates the risk in never-smokers 5 years after cessation. Quitting smoking has a greater impact on morbidity and mortality than changing diet, weight, or exercise. ${ }^{12}$ On the other hand, studies have shown that NRT is safe in patients with stable cardiovascular diseases. ${ }^{69}$ There is no evidence that bupropion use increases the cardiovascular risk of smokers. In view of the favorable risk-benefit ratio in patients with stable cardiovascular diseases, pharmacotherapy should be offered to this population of smokers. Physicians should adopt a more aggressive approach in this population, including the use of combination pharmacological therapy as these patients are likely to be more nicotine dependent.

\section{Smokers With Pulmonary Diseases}

Cigarette smoking is an important risk factor for pulmonary diseases, being responsible for 85000 deaths per year from respiratory diseases such as chronic obstructive pulmonary disease and pneumonia. ${ }^{70}$ Stopping smoking halts the smokinginduced accelerated decline in lung function seen with chronic obstructive pulmonary disease. ${ }^{12}$ Documented changes in pulmonary function may be used as a motivational factor for smoking cessation in these patients. As with patients with cardiovascular diseases, those who continue to smoke despite having pulmonary diseases are likely to be highly nicotine dependent ${ }^{71}$; hence, treatment with pharmacological agents is very important in this population of smokers.

\section{Light Smokers}

Current data suggest that $5 \%$ to $10 \%$ of smokers consume 5 or fewer cigarettes a day, ${ }^{72}$ although the proportion is much higher among African Americans and Hispanic populations. ${ }^{73}$ These smokers in general are not addicted to nicotine, and may abstain from smoking for days without significant withdrawal effects. ${ }^{74}$ Light smokers are invariably excluded in virtually all pharmacological smoking cessation trials. The quit rates of the pharmacological agents discussed herein were derived from studies in regular smokers who smoke 10 or more cigarettes a day. Consequently, there is insufficient data about effective smoking cessation interventions for light smokers. However, light smokers should equally be strongly encouraged to quit, as there is no safe level of smoking. It is logical that drug therapy should only be considered after nonpharmacological measures have failed.

\section{ADJUNCTIVE MATERIALS}

Primary care physicians should consider offering adjunctive materials to supplement educational and supportive counseling. All pharmacological agents discussed herein were approved to be used in conjunction with a behavioral smoking cessation program. Virtually all these products provide some form of selfhelp kits in their initial or starter packages. Some also provide smoking cessation videotapes and information about where smokers may call in to receive counseling. The American Lung Association has produced a number of materials, 2 publications of which are specifically

ARCH FAM MED/VOL 9, MAR 2000 WWW.ARCHFAMMED.COM 
produced for patients wishing to quit on their own: a 64-page cessation guide, Freedom From Smoking in 20 Days, and a 28-page maintenance booklet, A Lifetime of Freedom From Smoking. The National Cancer Institute has also produced many publications, including Clearing the Air, all of which are available free. A listing of these and other resources that may be helpful to both physicians and their patients is provided at the end of this article.

\section{GENERAL CONSIDERATIONS}

\section{Relapse}

Physicians should be aware that relapse is quite common among smokers both during and after cessation treatment. In fact, studies have shown that it takes an average of 4 to 5 quit attempts before eventual success at cessation. ${ }^{13}$ Patients should therefore be encouraged to try to quit again as soon as possible after a failed attempt. In assessing patients who relapse, physicians should address patient and treatment factors that may have contributed to the failed attempt. Patient factors include lack of motivation (provide motivational counseling such as discussing the pros and cons of smoking); environmental stressors such as death or illness within the family, loss of job, being around or living with other smokers (provide relevant counseling or refer as appropriate); and presence of comorbidities, especially alcohol abuse and depression as up to $20 \%$ of heavy smokers have current alcohol problems and $40 \%$ have a history of depression. ${ }^{75-77}$ Treatment considerations include adequacy of dosage (whether dose prescribed was adequate or patient used medication as prescribed), cost (whether prescription was affordable or was paid for by insurance plan), and drug adverse effects that affected treatment compliance. If the patient agrees to try again, a new quit date should be set. If dosage of the medication used in prior attempt was adequate, and relapse was due to uncontrolled withdrawal, the patient should be considered for combination treatment. We recommend a combination of one long-acting agent (trans- dermal nicotine patch or bupropion) plus a shorter-acting, quick-onset agent (nicotine polacrilex gum, nicotine inhaler, or nicotine nasal spray). Treatment should be continued for 3 to 6 months followed by 6 to 12 weeks of tapering of the shortacting nicotine product if necessary. Patients should be given adequate instructions in proper use of the medication and the necessary follow-up provided. Follow-up contact is vital and should be made within 1 week of the quit date because relapse rates are highest during the first few days after cessation. ${ }^{78,79}$ Follow-up could be in the office, by telephone, or by mail, and can be made by the physician or other trained office staff. We recommend that patients who relapse after 2 or 3 attempts despite adequate treatment and careful considerations of the factors discussed herein should be referred to a smoking cessation specialist.

\section{Addictive Potential}

Some studies have reported that 5\% to $20 \%$ of patients prescribed the polacrilex nicotine gum for smoking cessation continue to use the gum for 1 year or more. ${ }^{72,80}$ Although abrupt cessation of use of the gum can produce withdrawal symptoms similar to but milder than that from cigarettes, ${ }^{81}$ the use of the gum can be safely eliminated by gradual reduction. Long-term use may represent patient's desire to extend duration of therapy for fear of returning to smoking. ${ }^{82}$ Abrupt cessation of the transdermal nicotine patch does not appear to be associated with withdrawal symptoms. ${ }^{83}$ Nicotine nasal spray seems to have a higher potential for long-term use than the gum as evidenced by findings from clinical trials that up to $43 \%$ of those abstinent at 1 year were still using the spray at 1 year. ${ }^{41}$ Gradual dose reduction (over 1-3 months) should be implemented for those using the spray beyond 3 months. Long-term use did not appear to be a problem for the nicotine inhaler as all patients were able to discontinue inhaler use within 6 months in clinical trials. No problems with long-term use have been reported with bupropion.

\section{CHOICE OF PHARMACOLOGICAL AGENTS}

Given the many options of pharmacotherapy available for smoking cessation today, physicians are likely to be asked which of these products their patients should use. This situation is further compounded in managed care settings where health plans may recommend certain agents over others. Factors that should be considered in drug therapy include efficacy, cost, ease of use, adverse effect profile, and patient characteristics. There are limited data on the comparative efficacy of the 5 approved agents (Table 3) - nicotine polacrilex gum, transdermal nicotine patch, nicotine nasal spray, nicotine inhaler, and bupropion. In a recent study, Hajek et al $^{91}$ conducted a comparative trial of nicotine polacrilex gum, transdermal nicotine patch, nicotine nasal spray, and nicotine inhaler. These researchers found that the 4 NRTs did not differ in their effects on withdrawal discomfort, urges to smoke, or rates of abstinence with 12-week continuous abstinence rates of $20 \%, 21 \%, 24 \%$, and $24 \%$ for gum, patch, spray, and inhaler groups, respectively. In the same study, compliance was high for the patch (82\%), low for the gum (38\%), and very low for the spray (15\%) and the inhaler (11\%). The spray was underused because of adverse effects, and the inhaler was rated as more embarrassing to use than other products. These findings suggest that although the 4 products are equally efficacious, compliance and adverse event profile appear to favor the patch. However, that the higher compliance and lower adverse event rates did not lead to better quit rates in the patch group suggest that various NRTs may have different appeal and efficacy in different populations of smokers. In another study, Jorenby et $\mathrm{al}^{54}$ compared the efficacy of bupropion and nicotine patch as single agents and as combined therapy. The abstinence rates were $18.8 \%, 21.3 \%, 34.8 \%$, and $38.8 \%$ at 6 months, and $15.6 \%$, $16.4 \%, 30.3 \%$, and $35.5 \%$ at 12 months for placebo, nicotine patch only, bupropion only, and combined bupropion and nicotine patch, respectively. Although this study sug-

$\overline{\text { ARCH FAM MED/VOL 9, MAR } 2000 \text { WWW.ARCHFAMMED.COM }}$ 


\begin{tabular}{|c|c|c|c|c|c|c|}
\hline \multirow[b]{2}{*}{ Study } & \multicolumn{3}{|c|}{ Quit Rate at $6 \mathrm{mo}, \%$} & \multicolumn{3}{|c|}{ Quit Rate at $1 \mathrm{y}, \%$} \\
\hline & $\begin{array}{c}\text { Active } \\
\text { Treatment }\end{array}$ & Placebo & $P$ & $\begin{array}{l}\text { Active } \\
\text { Treatment }\end{array}$ & Placebo & $P$ \\
\hline \multicolumn{7}{|l|}{ Nicotine gum } \\
\hline Schneider et a $\left.\right|^{84}$ & 48.0 & 20.0 & $<.05$ & 30.0 & 20.0 & $<.05$ \\
\hline Lam et a $\left.\right|^{32}$ & 27.0 & 18.0 & $<.05$ & 23.0 & 13.0 & $<.05$ \\
\hline \multicolumn{7}{|l|}{ Nicotine patch } \\
\hline Hurt et al $\left.\right|^{85}$ & 29.2 & 15.0 & $<.05$ & 27.5 & 14.2 & $<.05$ \\
\hline Sachs et al ${ }^{86}$ & 33.6 & 12.1 & $<.05$ & 24.8 & 9.4 & $<.05$ \\
\hline Tonnesen et $\mathrm{al}^{87}$ & 19.3 & 2.8 & $<.05$ & 12.4 & 2.8 & $<.05$ \\
\hline \multicolumn{7}{|l|}{ Nicotine nasal spray } \\
\hline Blondal et a $\left.\right|^{88}$ & 29 & 18 & .05 & 25 & 17 & .09 \\
\hline Hjalmarson et al ${ }^{89}$ & 44 & 19 & $<.05$ & 34 & 18 & $<.05$ \\
\hline Schneider et al ${ }^{90}$ & 25 & 10 & $<.05$ & 18 & 8 & $<.05$ \\
\hline \multicolumn{7}{|l|}{ Nicotine inhaler } \\
\hline Leischow et al ${ }^{45}$ & 21.0 & 6.0 & $<.05$ & 11.0 & 5.0 & .14 \\
\hline Tonnesen et a $\left.\right|^{46}$ & 17.2 & 7.8 & $<.05$ & 15.2 & 5.0 & $<.05$ \\
\hline \multicolumn{7}{|c|}{ Bupropion hydrochloride } \\
\hline Hurt et al ${ }^{49}$ & 27 & 16 & $<.05$ & 23.1 & 12.4 & $<.05$ \\
\hline Jorenby et al ${ }^{54}$ & 34.8 & 18.8 & $<.001$ & 30.3 & 15.6 & $<.001$ \\
\hline
\end{tabular}

*These rates are derived from noncomparative studies, so quit rates can only be compared within rows but not across rows.

gests superior efficacy for bupropion over the patch, it is premature to draw conclusions or make recommendations based on a single study. The comparative efficacy and tolerability of all 5 products have not been reported in the literature. It is good judgment to consider using products with better compliance and fewer adverse events such as the transdermal patch before other NRTs. It is important to note, however, that certain patient characteristics such as preferences, comorbidities, experience in prior quit attempts, and degree of nicotine dependence may warrant use of the spray and inhaler as initial therapy. Bupropion may be used as initial therapy either alone or (for more nicotine-dependent patients) in combination with NRTs. Although there are anecdotal reports that some health plans are recommending bupropion as first-line therapy over the NRTs, such recommendations are not supported by current research. We recommend that physicians consider using an algorithm (Figure) to assist them in identification and triaging of therapy for smokers.

\section{CONCLUSIONS}

The recent increase in approved pharmacological options for smok- ing cessation provides primary care physicians with a wide range of treatment approaches. When used correctly, all currently approved products appear to be equally efficacious, approximately doubling quit rates compared with placebo. ${ }^{92}$ It is therefore logical that patient's preference, comorbidities, and adverse effect profile of individual agents should guide treatment choice. Increased access created by nonprescription availability of some NRTs has been credited with substantial increase in smokers quitting in the United States. ${ }^{93}$ Some studies reported finding no difference in abstinence rates with nonprescription use of nicotine patch compared with its use in prescription setting, suggesting physician advice had no effect in the use of these products. However, since the major role of physician advice is to motivate smokers to quit, ${ }^{94-96}$ failure to demonstrate a significant effect in the studies may be because these smokers were already motivated. Given the fact that primary care physicians have contact with $70 \%$ of smokers in a given year, they are in a unique position to influence a significant proportion of smokers. Physicians should be aware of the special needs of certain populations of smokers, including women, ethnic minorities, light smokers, and patients with cardiovascular and pulmonary diseases.

Given the proven effectiveness of smoking cessation interventions and their potential to reduce smoking-related morbidity and mortality, failure to identify, advise, and offer pharmacological agents to smokers may soon be judged as deviation from standard of care. Physicians may consider the efficacy of smoking cessation intervention as generally low compared with that of treatment with antibiotics or antihypertensives. However, smoking cessation should be put into proper perspective. If physicians achieve a $5 \%$ quit rate in $70 \%$ of the 50 million (35 million) smokers seen by primary care physicians yearly, this will result in 1.73 million smokers quitting each year. As physicians endeavor to educate and empower their patients with regard to their health, this significant contributor to personal and social morbidity cannot be ignored. Of all preventive care efforts, smoking cessation promotion has the potential to achieve the most dramatic reduction in morbidity and mortality, and improvement in public health. The ultimate disease prevention strategy would be to prevent initiation of smoking. In spite of widespread knowledge of health consequences, 3000 Americans, mostly teenagers and children, start smoking each day. Although we addressed the important role of pharmacotherapy of smoking cessation, it should be recognized that a sustained reduction in smoking prevalence will require a comprehensive population-based approach. Such an approach should include efforts aimed at reducing social desirability of smoking, limiting access to cigarettes, and increasing availability as well as utilization of effective cessation intervention. Finally, as efforts to promote smoking cessation interventions are sustained, we expect to see an increase in the provision of cessation interventions, increased quit rates, and an ultimate reduction in smoking-related morbidity and mortality.

Accepted for publication November 16, 1999.

$\overline{\text { ARCH FAM MED/VOL 9, MAR } 2000 \text { WWW.ARCHFAMMED.COM }}$ 


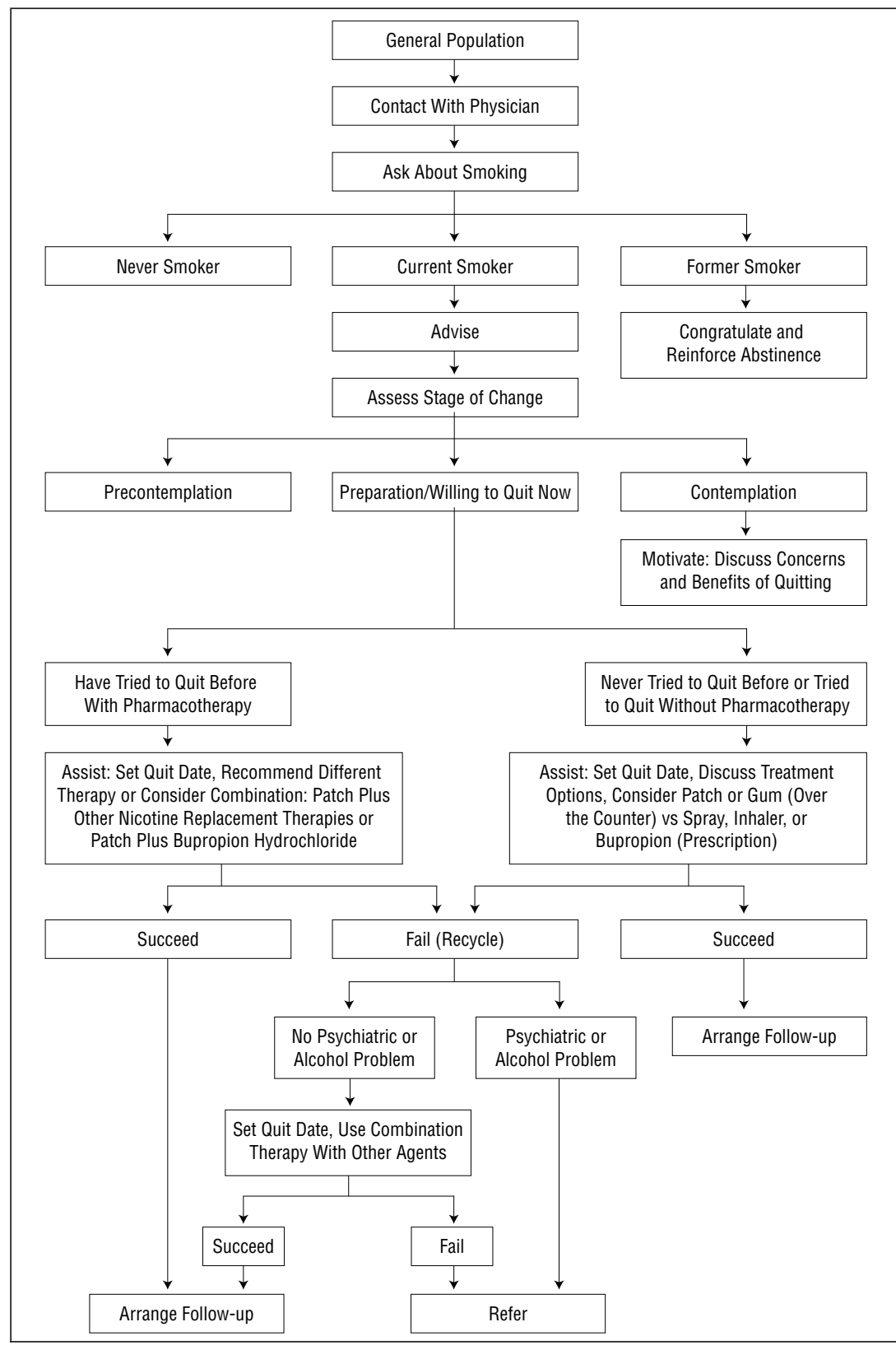

Algorithm for smoking cessation.

This work was supported in part by National Cancer Institute grants R01CA77856 and RO1CA778560351 and $a$ Robert Wood Johnson Generalist Physician Faculty Scholars Award (032586) to Dr Ahluwalia.

We thank Anne D. Walling, MD, for her assistance in the preparation of the manuscript.

Reprints: Kolawole S. Okuyemi, MD, MPH, Department of Family Medicine, School of Medicine, University of Kansas, 3901 Rainbow Blvd, Kansas City, KS 66160-7370 (e-mail: kokuyemi@kumc.edu).

\section{REFERENCES}

1. US Department of Health and Human Services Healthy People 2000. Washington, DC: US Government Printing Office; 1991. DHHS publication (PHS) 91-50212.

2. Centers for Disease Control and Prevention. Medical expenditure attributable to cigarette smokingUnited States, 1993. MMWR Morb Mortal Wkly Rep. 1994;43:469-472.

3. Centers for Disease Control and Prevention. Cigarette smoking among adults_-United States, 1993. MMWR Morb Mortal Wkly Rep. 1994;43:925930

4. Centers for Disease Control and Prevention. Statespecific prevalence among adults of current cigarette smoking and smokeless tobacco use and per capita tax-paid sales of cigarettes-United States, 1997. MMWR Morb Mortal Wkly Rep. 1998;47: 922-926.

5. US Department of Health and Human Services. Healthy People 2000 Review, 1994. Washington, DC: US Government Printing Office; 1994.

6. Physician and other health care professional counseling of smokers to quit-United States, 1991. MMWR Morb Mortal Wkly Rep. 1993;42:854857

7. Ockene JK. Physician-delivered interventions for smoking cessation: strategies for increasing effectiveness. Prev Med. 1987;16:723-737.

8. Samet JM. The health benefits of smoking cessation. Med Clin North Am. 1992;76:399-414.

9. FrankE. Benefits of stopping smoking. West J Med 1993;159:83-87.

10. Thun MJ, Day-Lally CA, Calle EE, Flanders WD, Heath CW Jr. Excess mortality among cigarette smokers: changes in a 20-year interval. Am J Public Health. 1995;85:1223-1230.

11. Harris RE, Zang EA, Anderson JI, et al. Race and sex differences in lung cancer risk associated with cigarette smoking. Int J Epidemiol. 1993;22:592599

12. US Department of Health and Human Services. The Health Benefits of Smoking Cessation. Washington, DC: Public Health Service, Center for Chronic Disease Prevention and Health Promotion, Office of Smoking and Health; 1990. DHHS publication (CDC) 90-8416.

13. US Department of Health and Human Services. The Health Consequences of Smoking: Nicotine Addiction: A Report of the Surgeon General. Rockville, Md: Public Health Service; 1988.

14. Anthony JC, Warner LA, Kessler RC. Comparative epidemiology of dependence on tobacco, alcohol, controlled substances, and inhalants: basic findings from the comorbidity survey. Exp Clin Psychopharmacol. 1994;2:244-268.

15. Fiscella K, Franks P. Cost-effectiveness of the transdermal nicotine patch as an adjunct to physicians' smoking cessation counseling. JAMA. 1996;275:1247-1251

16. Benowitz NL. Pharmacology of nicotine: addiction and therapeutics. Annu Rev Pharmacol Toxicol. 1996;36:597-613.

17. The Smoking Cessation Clinical Practice Panel and Staff. The Agency for Health Care Policy and Research Smoking Cessation Clinical Practice Guideline. JAMA. 1996;275:1270-1280.

18. Slama K, Redman S, Perkins J, Reid ALA, SansonFisher RW. The effectiveness of two smoking cessation programs for use in general practice: a randomized clinical trial. BMJ.1990;300:17071709.

19. Law M, Tang JL. An analysis of the effectiveness of interventions intended to help people stop smok ing. Arch Intern Med. 1995;155:1933-1941.

20. Gilchrist V, Miller RS, Gillanders WR, et al. Does family practice at residency teaching sites reflect community practice? J Fam Pract. 1993;37:555-563.

21. Lichtenstein E, Hollis JF. Patient referral to a smoking cessation program: who follows through? J Fam Pract. 1992;34:739-744.

22. Baillie AJ, Mattick RP, Hall W, Webster P. Metaanalytic review of the efficacy of smoking cessation interventions. Drug Alcohol Rev. 1994;13: 153-166

23. Schwartz JL. Methods of smoking cessation. Med Clin North Am. 1992;76:451-476.

24. Kottke TE, Battista RN, DeFriese GH, Brekke ML. Attributes of successful smoking cessation interventions in medical practice. JAMA. 1988;259: 2882-2889. 
25. Brigga GG, Freeman RK, Yaffe SJ. Drugs in Pregnancy and Lactation. Baltimore, Md: Williams \& Wilkins; 1994.

26. Hughes JR. Risk-benefit assessment of nicotine preparations in smoking cessation. Drug Safety. 1993;8:49-56.

27. Henningfield JE. Nicotine medications for smoking cessation. N Engl J Med. 1995;333:11961203.

28. Hjalmarson A, Franzon M, Westin A, Wiklund 0. Effect of nicotine nasal spray on smoking cessation: a randomized, placebo-controlled, doubleblind study. Arch Intern Med. 1994;154:25672572.

29. Hughes JR. Dependence potential and abuse liability of nicotine replacement therapies. Biomed Pharmacother. 1989;43:11-17.

30. Hughes JR, Gust SW, Keenan R, Fenwick JW, Skoog K, Higgins ST. Long-term use of nicotine vs placebo gum. Arch Intern Med. 1991;151:19931998.

31. Capeda BA. Meta-analytical review of the efficacy of nicotine chewing gum in smoking treatment programs. J Consult Clin Psychol. 1993;61: 822-830.

32. Lam W, Sze PC, Sacks HS, Chalmers TC. Metaanalysis of randomized controlled trials of nicotine chewing-gum. Lancet. 1987;2:27-30.

33. Benowitz NL. Pharmacologic aspects of cigarette smoking and nicotine addiction. NEng/ J Med. 1988;319:1318-1330.

34. Orleans CT, Resch N, Noll E, et al. Use of transdermal nicotine in a state-level prescription plan for the elderly. JAMA. 1994;271:601-607.

35. Silagy C, Mant D, Fowler G, Lodge M. Metaanalysis on efficacy of nicotine replacement therapies in smoking cessation. Lancet. 1994;343:139142.

36. Ahluwalia JS, McNagny SE, Clark WS. Smoking cessation among inner-city African Americans using the nicotine transdermal patch. J Gen Intern Med. 1998;13:1-8.

37. Fiore MC, Smith SS, Jorenby DE, Baker TB. The effectiveness of the nicotine patch for smoking cessation. JAMA. 1994;271:1940-1947.

38. Leischow SJ, Castellini S, Merikle E. The efficacy of nicotine patch as an over-the-counter medication. J Addict Dis. 1997:16:140.

39. Hays JT, Croghan IT, Offord KP, et al. Over-thecounter (OTC) transdermal nicotine patch therapy. J Addict Dis. 1997;16:136.

40. Schneider NG, Lunell E, Olmstead RE, Fagerstrom KO. Clinical pharmacokinetics of nasal nicotine delivery: a review and comparison to other nicotine systems. Clin Pharmacokinet. 1996;31: 65-80.

41. Sutherland G, Stapleton JA, Russel MAH, et al. Randomized controlled trial of nasal nicotine spray in smoking cessation. Lancet. 1992;340:324329.

42. McNeil Consumer Products. Physicians'Desk Reference. 52nd ed. Montvale, NJ: Medical Economics Co; 1998:1545-1548.

43. Bergstorm M, Nordberg A, Lunell E, Antoni G, Landstrom B. Regional deposition of inhaled ${ }^{11} \mathrm{C}$ nicotine vapor in human airway as visualized by positron emission tomography. Clin Pharmacol Ther. 1995;57:309-317.

44. Schneider NG, Olmstead R, Nilsson F, Mody FV, Franzon M, Doan K. Efficacy of a nicotine inhaler in smoking cessation: a double-blind, placebocontrolled trial. Addiction. 1996;91:1293-1306.

45. Leischow SJ, Nilsson F, Franzon M, Hill A, Otte $\mathrm{P}$, Merikle EP. Efficacy of the nicotine inhaler as an adjunct to smoking cessation. Am J Health
Behav. 1996;20:364-371.

46. Tonnesen P, Norregaard J, Mikkelsen K, et al. A double-blind trial of nicotine inhaler for smoking cessation. JAMA. 1993;269:1268-1271.

47. Ascher JA, Cole JO, Colin J, et al. Bupropion: a review of its mechanism of antidepressant activity. J Clin Psychiatry. 1995;56:395-401.

48. Glaxo Wellcome Inc. Physicians' Desk Reference. 52nd ed. Montvale, $\mathrm{NJ}$ : Medical Economics Co; 1998:1139-1144.

49. Hurt RD, Sachs DPL, Glover ED, et al. A comparison of sustained-release bupropion and placebo for smoking cessation. N Engl J Med. 1997;337: 1195-1202.

50. Ferry LH, Burchette RJ. Efficacy of bupropion for smoking cessation in non-depressed smokers. J Addict Dis. 1994;13:249.

51. Kornitzer M, Boutsen M, Thijs J, et al. Combined use of nicotine patch and gum in smoking cessation: a placebo-controlled clinical. Prev Med. 1995;24:41-47.

52. Fagerstrom KO. Combined use of nicotine replacement products. Health Values. 1994;18:1520.

53. Blondal T, Gudmundsson LJ, Olafsdottir I, Gustavsson G, Westin A. Nicotine nasal spray with nicotine patch for smoking cessation: randomized trial with six year follow up. BMJ. 1999;318: 285-288.

54. Jorenby DE, Leischow SJ, Nides MA, et al. A controlled trial of sustained-release bupropion, a nicotine patch, or both for smoking cessation. N Engl J Med. 1999;340:685-691.

55. US Department of Health and Human Services. Tobacco Use Among US Racial/Ethnic Minority Groups-African Americans, American Indians and Alaska Natives, Asian American and Pacific Islanders, and Hispanics: A Report of the Surgeon General. Atlanta, Ga: US Dept of Health and Human Services, Centers for Disease Control and Prevention, National Center for Chronic Disease Prevention and Health Promotion, Office of Smoking and Health; 1998.

56. Centers for Disease Control. Cigarette smoking among blacks and other minority populations. MMWR Morb Mortal Wkly Rep. 1987;36:405407.

57. US Department of Health and Human Services. Reducing the Health Consequences of Smoking: 25 Years of Progress: A Report of the Surgeon General. Washington, DC: US Dept of Health and Human Services, Public Health Service, Centers for Disease Control, Center for Chronic Disease Prevention and Health Promotion, Office on Smoking and Health; 1989. DHHS publication (CDC) 898411.

58. Fiore MC, Novotny TE, Pierce JP, Hatziandreu EJ, Patel KM, Davis RM. Trends in cigarette smoking in the US: the changing influence of gender and race. JAMA. 1989;261:49-55.

59. Leischow SJ, Hill A, Cook G. The effects of transdermal nicotine for the treatment of Hispanic smokers. Am J Health Behav. 1996;20:304-311.

60. Parker SL, Tong T, Bolden S, Wingo PA. Cancer statistics, 1997. Cancer J Clin. 1997;47:5-27.

61. Grunberg NE, Winders SE, Wewers ME. Gender differences in tobacco use. Health Psychol. 1991; 10:143-153.

62. Solomon LJ, Flynn BS. Women who smoke. In: Orleans CT, Slade JD, eds. Nicotine Addiction: Principles and Management. New York, NY: Oxford University Press; 1993:339-349.

63. Gourlay SG, Benowitz NL. Is clonidine an effective smoking cessation therapy? Drugs. 1995;50: 197-207.
64. US Department of Health and Human Services. The Health Consequences of Smoking for Women: A Report of the Surgeon General. Washington, DC: US Government Printing Office; 1980.

65. Burling TA, Bigelow GE, Robinson JC, Mead AM. Smoking during pregnancy: reduction via objective assessment and directive advice. Behav Ther 1991:22:31-40.

66. Gritz ER, Kristeller JL, Burns DM. Treating nicotine addiction in high risk groups and patients with medical co-morbidity. In: Orleans CT, Slade JD, eds. Nicotine Addiction: Principles and Management. New York, NY: Oxford University Press; 1993:279-309.

67. Benowitz NL. Nicotine replacement therapy during pregnancy. JAMA. 1991;266:3174-3177.

68. Centers for Disease Control and Prevention. Cigarette smoking among adults—United States, 1991. MMWRMorb Mortal Wkly Rep. 1993;42:230-233.

69. Working Group for the Study of Transdermal Nicotine in Patients With Coronary Artery Disease. Nicotine replacement therapy for patients with coronary artery disease. Arch Intern Med. 1994;154:989-995

70. Centers for Disease Control and Prevention. Cigarette smoking -attributable mortality and years of potential life lost, United States, 1990. MMWR Morb Mortal Wkly Rep. 1993;42:645-649.

71. Kennnedy JA, Crowley TJ, Cottler LB, Mager DE. Substance use diagnoses in patients with lung disease. Am J Addict. 1993:2:126-130.

72. US Department of Health and Human Services. The Health Consequences of Smoking: Nicotine Addiction: A Report of the Surgeon General, 1988. Atlanta, Ga: Centers for Disease Control, Office on Smoking and Health; 1988. DHHS publication (CDC) 88-8406

73. Evans NJ, Gilpin E, Pierce JP, et al. Occasional smoking among adults: evidence from the California survey. Tob Control. 1992;1:169-175.

74. Shiffman S, Fisher LB, Zettler-Segal M, Benowitz NL. Nicotine exposure among nondependent smokers. Arch Gen Psychiatry. 1990;47:333-336.

75. Hughes JR. Smoking and alcoholism. In: Hatsukami DK, Cox J, eds. Behavioral Approaches to Addiction. New York, NY: Calmers; 1994:1-3.

76. Glassman AH. Cigarette smoking: implications for psychiatric illness. Am J Psychiatry. 1993;150: 546-553.

77. Hall SM, Munoz RF, Reus VI, Sees KL. Nicotine, negative affect, and depression. J Consult Clin Psychol. 1993;61:761-767.

78. Hughes JR, Gulliver SB, Fenwick JW, et al. Smoking cessation among self-quitters. Health Psychol. 1992;11:331-334.

79. Kottke TE, Brekke ML, Solberg LI, Hughes JR. A randomized trial to increase smoking intervention by physicians: doctors helping smokers, round 1. JAMA. 1989;261:2101-2106

80. Hughes JR, Gust SW, Keenan R, et al. Longterm use of nicotine vs placebo gum. Arch Intern Med. 1991;151:1993-1998.

81. Hughes JR. Dependence potential and abuse liability of nicotine replacement therapies. Biomed Pharmacother. 1989;43:11-17.

82. American Psychiatric Association. Practice guideline for the treatment of patients with nicotine dependence. Am J Psychiatry. 1996;153(suppl):1-31

83. Fiore MC, Jorenby DE, Baker TB, Kenford SL. Tobacco dependence and the nicotine patch: clinical guidelines for effective use. JAMA. 1992;268: 2687-2694.

84. Schneider NG, Jarvik ME, Forsythe AB, Read LL, Elliot ML. Nicotine gum in smoking cessation: a placebo controlled, double-blind trial. Addict Behav. 1983;8:253-261. 
85. Hurt RD, Dale LC, Fredrickson PA, et al. Nicotine patch therapy for smoking cessation combined with physician advice and nurse follow-up. JAMA. 1994;271:595-600.

86. Sachs DPL, Sawe U, Leischow SJ. Effectiveness of a 16-hour transdermal nicotine patch in medical practice setting, without intensive group counseling. Arch Intern Med. 1993;153:1881-1890.

87. Tonnesen P, Norregaard J, Simonsen K, Sawe U. A double-blind trial of a 16-hour transdermal nicotine patch in smoking cessation. N Engl J Med. 1991;325:311-315.

88. Blondal T, Franzon M, Westin A. A double-blind randomized trial of nicotine nasal spray as an aid in smoking cessation. Eur Respir J. 1997;10: 1585-1590.

89. Hjalmarson A, Franzon M, Westin A, Wiklund 0. Effect of nicotine nasal spray on smoking cessation. Arch Intern Med. 1994;154:2526-2572.

90. Schneider NG, Olmstead R, Mody FV, et al. Efficacy of a nicotine nasal spray in smoking cessation: a placebo-controlled, double-blind trial. Addiction. 1995;90:1671-1682.

91. Hajek P, West R, Foulds J, Nilsson F, Burrows S, Meadow A. Randomized comparative trial of nicotine polacrilex, a transdermal patch, nasal spray, and an inhaler. Arch Intern Med. 1999;159:20332038.

92. Hughes JR, Goldstein MG, Hurt RD, Shiffman S. Recent advances in the pharmacotherapy of smoking. JAMA. 1999;281:72-76.

93. Burton SL, Kemper KE, Baxter TA, Shiffman S, Gitchell J, Currence C. Impact of promotion of the
Great American Smokeout and availability of overthe-counter nicotine medications. MMWR Morb Mortal Wkly Rep. 1997;46:867-871.

94. Baillie A, Mattick RP, Hall W, Webster P. Metaanalytic review of the efficacy of smoking cessation interventions. Drug Alcohol Rev. 1994;13: 157-170.

95. Kottke TE, Battista RN, DeFriese GH, Brekke ML. Attributes of successful smoking cessation interventions in medical practice. JAMA. 1988;259: 2882-2889.

96. Law M, Tang JL. An analysis of the effectiveness of interventions intended to help people stop smoking. Arch Intern Med. 1995;155:1933-1941.

\section{SUGGESTED HELPS}

1. The American Lung Association (ALA) offers several manuals, including Freedom From Smoking in 20 Days (how to quit), A Lifetime of Freedom From Smoking (avoiding relapse), and Freedom From Smoking for You and Your Baby (a quit program for pregnant women). A contribution of $\$ 7$ is requested for the manuals, which can be obtained through local ALA chapters, or by writing the American Lung Association, 1740 Broadway, New York, NY 10019. Telephone (800) LUNG-USA. Internet: http://www.lungsusa.org.

2. The American Heart Association offers free publications including Calling It Quits, Smoking and Heart Disease, Smoking and Strokes: Two Things You Can Live Without, and Children and Smoking: AMessage to Parents. Contact a local chapter, or write the American Heart Association, 7272 Greenville Ave, Dallas, TX 75231. Telephone (800) AHA-USA1 (242-8721). Internet: http://www.americanheart.org.

3. The American Cancer Society offers a wide variety of materials including antismoking programs aimed at young people. Consult a local chapter to obtain materials, or write the American Cancer Society, 1599 Clifton Rd NE, Atlanta, GA 30329 Telephone: (800) ACS-2345. Internet: http:// www.cancer.org.

4. The National Cancer Institute offers free publications Quit for Good and Clearing the Air. Call (800) 4-CANCER (422-6237). Internet: http://www .nci.nih.gov.

5. National Heart, Lung, and Blood Institute, Building 31, Room 4A21, Bethesda, MD 20892. Telephone (301) 496-4236.

6. Nicotine Anonymous, PO Box 591777, San Francisco, CA 94159-1777. Telephone (415) 750-0328.

7. American Academy of Family Physicians (AAFP) offers the "AAFP Stop Smoking Kit" for use in office practice, with audiotapes for physicians and office staff, a charting system, and self-help materials for patients. The cost is $\$ 60$ for AAFP members and $\$ 90$ for nonmembers. Call (800) 274-2237, ext 5500.

8. Kits that come alongside the display or with the purchase of nicotine replacement products and bupropion, including such helps as a toll-free counseling telephone number, a smoking cessation guide, and/or smoking cessation videotapes.

Clinical Pearl

\section{Spironolactone for Heart Failure}

In a large randomized trial of patients with severe heart failure (left ventricular ejection fracture of no more than 0.35 ), at a mean follow-up of 2 years, patients in the group that received $25 \mathrm{mg}$ of spironolactone had a relative risk of death of 0.70 (95\% CI, 0.60-0.82; P<.001) compared with the group that received placebo. The patients who received spironolactone also had fewer hospital admissions and better cardiac function status. Gynecomastia or breast pain was reported by $10 \%$ of the men who received spironolactone. (N Engl J Med. 1999;341:709-717.) 